\title{
Iodine monoxide at a clean marine coastal site: observations of high frequency variations and inhomogeneous distributions
}

\author{
R. Commane ${ }^{1, *}$, K. Seitz ${ }^{2}$, C. S. E. Bale ${ }^{1}$, W. J. Bloss ${ }^{3}$, J. Buxmann ${ }^{2}$, T. Ingham ${ }^{1,4}$, U. Platt ${ }^{2}$, D. Pöhler ${ }^{2}$, and \\ D. E. Heard ${ }^{1,4}$ \\ ${ }^{1}$ School of Chemistry, University of Leeds, LS2 9JT, UK \\ ${ }^{2}$ Institute of Environmental Physics, University of Heidelberg, Germany \\ ${ }^{3}$ School of Geography, Earth and Environmental Sciences, University of Birmingham, \\ B15 2TT, UK \\ ${ }^{4}$ National Centre for Atmospheric Science, University of Leeds, Leeds, LS2 9JT, UK \\ *now at: School of Engineering and Applied Sciences, Harvard University, MA, USA
}

Received: 24 January 2011 - Published in Atmos. Chem. Phys. Discuss.:

Revised: - Accepted: 27 January 2011 - Published: 13 July 2011

\begin{abstract}
The first in situ point observations of iodine monoxide (IO) at a clean marine site were made using a laser-induced fluorescence instrument deployed at Mace Head, Ireland in August 2007. IO mixing ratios of up to $49.8 \mathrm{pptv}$ (equivalent to $\mathrm{pmol} \mathrm{mol}^{-1} ; 1 \mathrm{~s}$ average) were observed at day-time low tide, well in excess of previous observed spatially-averaged maxima. A strong anti-correlation of IO mixing ratios with tide height was evident and the high time resolution of the observations showed IO peaked in the hour after low tide. The temporal delay in peak IO compared to low tide has not been observed previously but coincides with the time of peak aerosol number previously observed at Mace Head.

A long path-differential optical absorption spectroscopy instrument (with a $2 \times 6.8 \mathrm{~km}$ folded path across Roundstone Bay) was also based at the site for 3 days during the point measurement observation period. Both instruments show similar temporal trends but the point measurements of IO are a factor of $\sim 6-10$ times greater than the spatially averaged IO mixing ratios, providing direct empirical evidence of the presence of inhomogeneities in the IO mixing ratio near the intertidal region.
\end{abstract}

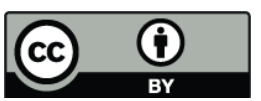

Correspondence to: D. E. Heard

(d.e.heard@leeds.ac.uk)

\section{Introduction}

The important role of iodine chemistry in the marine boundary layer has been highlighted by a number of studies (e.g., Alicke et al., 1999; Read et al., 2008; O'Dowd et al., 2002). The iodine monoxide (IO) radical is involved in the catalytic destruction of ozone in the marine boundary layer (Davis et al., 1996). This destruction can be initiated by the reaction of $\mathrm{IO}$ with itself or $\mathrm{BrO}$ as well as with the $\mathrm{HO}_{2}$ radical or $\mathrm{NO}_{2}$. The reaction of $\mathrm{IO}$ with $\mathrm{HO}_{2}$ alters the $\mathrm{OH} / \mathrm{HO}_{2}$ ratio (Bloss et al., 2005) and affects the oxidising capacity of the atmosphere, both directly (through $\mathrm{HO}_{\mathrm{x}}$ ) or indirectly through impacts on $\mathrm{O}_{3}$ and $\mathrm{NO}_{\mathrm{x}}$.

Iodine has been found in ultrafine particles (Mäkelä et al., 2002) and observations in marine environments have shown that peaks in gas phase $\mathrm{I}_{2}$ concentrations coincide with new particle bursts (O'Dowd et al., 2002; Sellegri et al., 2005; McFiggans et al., 2010). However, the mechanism of new particle formation from iodine is still uncertain. Recent laboratory work suggests that $\mathrm{IO}$ and $\mathrm{OIO}$ react to form higher oxides $\mathrm{I}_{2} \mathrm{O}_{3}$ and $\mathrm{I}_{2} \mathrm{O}_{4}$, which then polymerise and grow to ultrafine particles (Saunders et al., 2010). If these new particles grow to form cloud condensation nuclei (CCN), they can influence cloud properties and have an impact on climate (Rosenfeld et al., 2008). Laboratory and modelling studies by Burkholder et al. (2004) suggested point mixing ratios of IO between 50 and $100 \mathrm{pptv}$ (parts-per-trillion, equivalent to pmol mol${ }^{-1}$ ) were required to explain the particle bursts observed in coastal areas (O'Dowd et al., 2002).

Published by Copernicus Publications on behalf of the European Geosciences Union. 
Table 1. Acronyms used are explained in the text.

\begin{tabular}{|c|c|c|c|c|}
\hline \multicolumn{5}{|c|}{ Summary of mid-latitude coastal IO Observations } \\
\hline Location \& Year & $\begin{array}{l}\text { Max IO (pptv); } \\
\text { Integration Time }\end{array}$ & Technique & Notes & Reference \\
\hline Mace Head, 2007 & $49.8 \pm 8.8 ; 1 \mathrm{~s}$ & LIF (in situ) & clean marine; & This study \\
\hline Mace Head, 2007 & $4.4 ; 10 \mathrm{~min}$ & LP-DOAS (13.6 km) & macroalge & Seitz et al. (2010) \\
\hline Mace Head, 2002 & $7.0^{\mathrm{a}}$ & LP-DOAS (8 km) & beds located & Saiz-Lopez et al. (2006b) \\
\hline Mace Head, 1998 & $7.2^{\mathrm{a}}$ & LP-DOAS (13.6 km) & all around & Carpenter et al. (2001) \\
\hline Mace Head, 1997 & $6.7^{\mathrm{a}}$ & LP-DOAS (13.6 km) & & Alicke et al. (1999) \\
\hline Mweenish Bay, 2007 & $29.9 ; 10 \mathrm{~min}$ & LP-DOAS (517 m) & South of MHD & Seitz et al. (2010) \\
\hline Dagebüll, Germany, 2002 & $1.9 ; 5-15 \mathrm{~min}$ & LP-DOAS (18.3 km) & semi-polluted & Peters et al. (2005) \\
\hline Roscoff, France, 2006 & $27.6 \pm 3.2 ; 10 \mathrm{~s}$ & LIF (in situ) & semi-polluted & Whalley et al. (2007) \\
\hline Roscoff, France, 2006 & $10.1^{\mathrm{a}}$ & LP-DOAS (6.7 km) & & Mahajan et al. (2009) \\
\hline Lilia, France, 2003 & $8 ; 5-15 \mathrm{~min}$ & LP-DOAS (18.8 km) & semi-polluted & Peters et al. (2005) \\
\hline $\begin{array}{l}\text { Appledore Is, Maine, } \\
\text { USA, } 2004\end{array}$ & $4^{\mathrm{a}}$ & LP-DOAS (4.6 km) & $\begin{array}{r}\text { semi-polluted } \\
\mathrm{NO}_{2} \text { up to } 8 \mathrm{ppbv}\end{array}$ & Stutz et al. (2007) \\
\hline
\end{tabular}

LP-DOAS: Long-path Differential Optical Absorption Spectroscopy. LIF: Laser-induced Fluorescence. CRDS: Cavity Ring Down Spectroscopy; ${ }^{\text {a }}$ No integration time given. ppbv $=$ parts-per-billion, equivalent to $\mathrm{nmol} \mathrm{mol}^{-1}$.

IO radicals are formed through the reaction of atomic iodine with ozone. A steady state between IO and I atoms is formed during the day, with the reformation of ozone in the absence of other reactions. In coastal areas, iodine atoms can be formed by the photolysis of molecular iodine or iodocarbons, which have been emitted from macroalgae in the intertidal zone and high concentrations of iodine atoms have been directly measured at coastal sites (Bale et al., 2008; Mahajan et al., 2011). IO was first observed at Mace Head Atmospheric Research Station (MHD), located on the west coast of Ireland, in 1997 by Long Path Differential Optical Absorption Spectroscopy (LP-DOAS) (Alicke et al., 1999) and has since been measured at a number of mid-latitude sites such as Lilia, France (Peters et al., 2005), Dagebüll, Germany (Peters et al., 2005) and Roscoff, France (Mahajan et al., 2009), with varying IO mixing ratios observed, up to a maximum of $29 \pm 8.8$ pptv observed by Seitz et al. (2010) at Mweenish Bay just south of Mace Head on the west coast of Ireland. These previous spatially-averaged observations of IO at MHD have provided important information about the role of macroalgae in initiating iodine chemistry through the emission of molecular iodine (e.g., Saiz-Lopez and Plane, 2004) and, to a lesser extent, iodocarbons (e.g., Carpenter et al., 2001). These studies also linked iodine species to new particle formation (O'Dowd et al., 2002) and initiated chamber studies into the role of specific macroalgae in the emission of iodine (Bale et al., 2008; Dixneuf et al., 2009; Ball et al., 2010).

Most field observations of IO have been made by LPDOAS instruments, which use path lengths of several kilometres to improve the LP-DOAS sensitivity (e.g. Carpenter et al., 2001; Saiz-Lopez and Plane, 2004; Peters et al., 2005; Saiz-Lopez et al., 2006a; Read et al., 2008; Mahajan et al., 2009; Seitz et al., 2010). Table 1 presents an overview of these spatially-averaged IO observations as well as point measurements of IO at mid-latitude locations. This significant spatial averaging can conceal the presence of an inhomogeneous distribution of the target species along the LPDOAS light-path, which can make the interpretation of point observations of short-lived species (e.g. $\mathrm{OH}$ and $\mathrm{HO}_{2}$ ) difficult. A factor of 10 increase in the IO concentration observed by LP-DOAS was required to reproduce $\left[\mathrm{HO}_{\mathrm{x}}\right]$ observed during the North Atlantic Marine Boundary Layer Experiment (NAMBLEX) campaign (Sommariva et al., 2006). A recent LP-DOAS study with various path lengths found similar IO column densities for both a $2 \mathrm{~km}$ and $10 \mathrm{~km}$ path length above beds of macroalgae, indicating the presence of significant inhomogeneities within the light path (Seitz et al., 2010).

We present point observations of IO made using a portable and compact Laser-Induced Fluorescence (LIF) instrument developed for the detection of IO. The instrument and calibration method are described. The temporal and tidal related variations of the in situ point observations of IO are discussed and the short-term variability investigated. The point observations of IO are compared to the spatially-averaged IO observations made by the LP-DOAS instrument and the extent of the inhomogeneity of the IO concentrations is examined. 

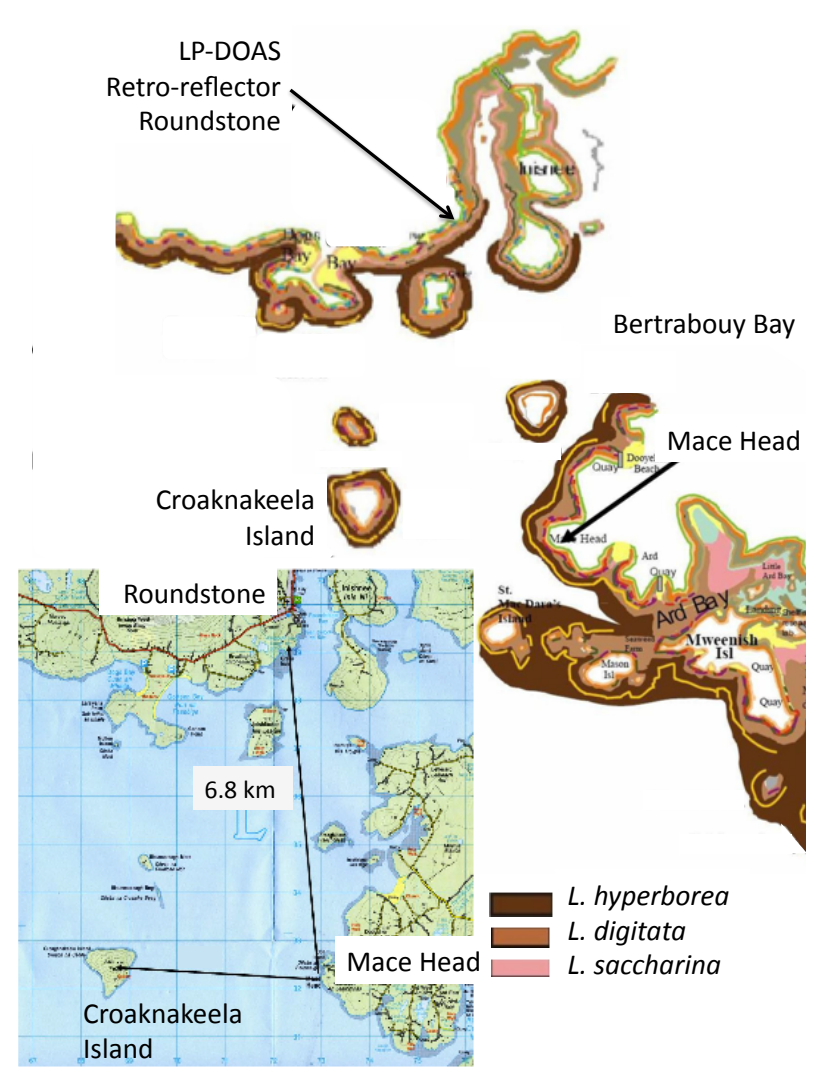

Fig. 1. Schematic representation of macroalgae location recorded during a 2000 survey. Extensive Laminaria beds were observed in the inter-tidal areas under the LP-DOAS light path. Adapted from Connemara Seaweed Survey 2001. Irish Seaweed Centre, NUIG Internal report $72 \mathrm{pp}$. (Bottom Left): ordinance Survey Map of Mace Head showing the $6.8 \mathrm{~km}$ LP-DOAS light path between Mace Head and Roundstone to the north. Croagnakeela Island $4.2 \mathrm{~km}$ to the west has been used as the location of the retro-reflector in previous studies.

\section{Instrumentation}

\subsection{Site description}

The Mace Head Atmospheric Research Station (MHD) $\left(53.32^{\circ} \mathrm{N}, 9.90^{\circ} \mathrm{W}\right)$ is a marine site located on the west coast of Ireland (Fig. 1). The research station has been the subject of extensive halogen studies in the past (e.g., Alicke etal., 1999; Saiz-Lopez et al., 2006a) and is described extensively in Heard et al. (2006).

Mace Head experiences semi-diurnal tides, with extensive beds of macroalgae exposed in narrow strips along the coast at low tides. A log of the approximate low and high tide times at the site was maintained during August 2007 and the high and low tide times were found to agree well with the tide times predicted for Roundstone Bay ( $7 \mathrm{~km}$ north) by the UK Hydrographic Office (UKHO) Poltis program. During the measurement period, the intertidal height in Round- stone Bay varied between $1 \mathrm{~m}$ at Neap Tide and $4.5 \mathrm{~m}$ at Spring Tide, which corresponds to a horizontal distance of between $\sim 50 \mathrm{~m}$ (high tide) and $\sim 100 \mathrm{~m}$ (low tide) in front of the site. During the observation period, the wind direction varied from west to north-west, with wind speeds varying from $11 \mathrm{~m} \mathrm{~s}^{-1}$ to $0.5 \mathrm{~m} \mathrm{~s}^{-1}$ (data courtesy of B. Kelly, Met Éireann). Multiple ensemble back trajectories wind fields calculated using the HYSPLIT (HYbrid Single-Particle Lagrangian Integrated Trajectory) model (NOAA Air Research Laboratory: Draxler and Hess, 1998) show this air had travelled at low level over the ocean for most of the previous $24 \mathrm{~h}$. Previous studies by Sommariva et al. (2006) found that clean marine air with $\mathrm{NO}<30 \mathrm{pptv}$ arrived at the site for these wind directions. During the August 2007 measurement period, NO was measured using a TECO Trace Level analyser with a limit of detection of $50 \mathrm{pptv}$ and $\mathrm{NO}$ was not recorded above this limit during the measurement period discussed here. The analyser recorded a short-lived increase in NO when a speedboat passed the site but this occurred during a calibration of the LIF system so has not been considered here.

Point measurements of IO were made on eight days between 15 and 30 August 2007 with short breaks in data collection due to restrictions on the deployment of the sampling cell i.e. observations were only possible when the station was attended and were not possible during inclement weather conditions brought by easterly winds. The instrument was installed in a van located $\sim 5 \mathrm{~m}$ north of the site buildings. The portable fluorescence cell was extended $10 \mathrm{~m}$ away from the van, towards the sea (upwind), giving it $\sim 5 \mathrm{~m}$ clearance in front of the site buildings, approximately $100 \mathrm{~m}$ from the low tide line and exposed macroalgae. Simultaneous spatiallyaveraged measurements were made by the LP-DOAS instrument for the final three LIF observation days (28-30 August 2007). The LP-DOAS instrument was located in the site buildings with the light-path passing $5 \mathrm{~m}$ behind the LIF fluorescence cell to a retro-reflector located across Roundstone Bay (total path length $13.6 \mathrm{~km}$ ).

\subsection{Laser-induced fluorescence instrument}

The laser-induced fluorescence (LIF) instrument uses radiation at $\lambda=444.885 \mathrm{~nm}$ (generated by a tunable solid state laser) to excite the $(2,0)$ band of the $A^{2} \Pi_{3 / 2} \leftarrow X^{2} \Pi_{3 / 2}$ electronic transition (R1 bandhead), which consists of several overlapping rotational lines (Gravestock et al., 2010). Off-resonance fluorescence in the $(2,5)$ band is detected at $\lambda=520.3 \mathrm{~nm}$.

The instrument was adapted from the Leeds aircraft instrument for $\mathrm{OH}$ and $\mathrm{HO}_{2}$ measurements (Commane et al., 2010) and the laser configuration used was similar to that described in Whalley et al. (2007) and Furneaux et al. (2010), with up to $100 \mathrm{~mW}$ of blue light at $\lambda \approx 445 \mathrm{~nm}$ produced. Details of the laser excitation and fluorescence spectra, and 


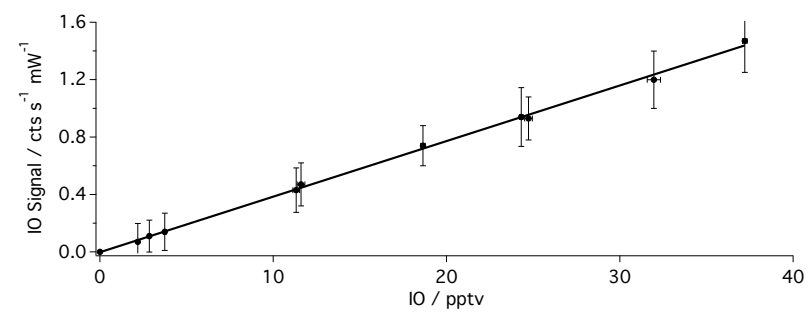

Fig. 2. Calibration of IO for mixing ratios between 2.2 and $37.2 \mathrm{pptv}$. From this fit, the sensitivity of the instrument $\left(C_{\mathrm{IO}}\right)$ is $0.039( \pm 0.001) \mathrm{cts} \mathrm{s}^{-1} \mathrm{~mW}^{-1} \mathrm{pptv}^{-1}$, with a slight negative intercept $\left(-0.002( \pm 0.01)\right.$ cts s$\left.^{-1} \mathrm{~mW}^{-1}\right), R=0.999$.

the photophysical and collisional processes occurring in the $A^{2} \Pi_{3 / 2}$ state of IO can be found in Gravestock et al. (2010). Installed on two aircraft racks, with a separate pump set, calibration system and portable fluorescence cell, the instrument was characterised prior to, and calibrated during, deployment at Mace Head.

The optical cell is similar in design to that described in Commane et al. (2010), with an extended inlet to reduce solar scattered light. The inlet was pointed vertically upwards and consisted of a $45 \mathrm{~mm}$ internal diameter stainless steel cylinder, with a $25 \mathrm{~mm}$ internal diameter solid nylon cylinder of $21.5 \mathrm{~cm}$ length inserted between a stainless steel cap and base, giving a total length of $33 \mathrm{~cm}$. A maximum of $\approx 5 \mathrm{cts}$ (counts) $\mathrm{s}^{-1}$ of solar scattered light was observed within the cell at solar noon. A $0.8 \mathrm{~mm}$ pinhole was centered on a flat disc, drawing ambient air into the fluorescence cell at a flow rate of $8.5 \mathrm{slm}$ (standard litres per minute, $20^{\circ} \mathrm{C}, 760$ Torr), giving an cell pressure of $\sim 150$ Torr.

Laser radiation was delivered to the cell through a $15 \mathrm{~m}$ fibre optic cable (Oz Optics) and the light exiting the fibre was collimated and focussed through a baffled side-arm into the fluorescence region. Fluorescence was detected on an axis perpendicular to both the laser beam and ambient airflow, and passed through a $50.2 \mathrm{~mm}$ diameter window (with $\lambda=521 \mathrm{~nm}$ anti-reflection coating), was collimated and filtered by a $\lambda=521 \mathrm{~nm}$ centred interference filter (Barr Associates, $2 \mathrm{~nm}$ FWHM, $52 \%$ transmission) and focussed through two lenses $(50.2 \mathrm{~mm}$ diameter, $52 \mathrm{~mm}$ focal length, anti-reflection coated for $\lambda=521 \mathrm{~nm}$ ) onto the photocathode of a yellow sensitive channel photomultiplier (CPM) (Perkin Elmer, C993 P). The signal from the CPM was sent to a photon-counting card (Becker and Hickl, MSA 300) in the data-acquisition computer before the signal was processed. The photon-counting card was triggered by a timed-transistor logic (TTL) pulse from the delay generator $50 \mathrm{~ns}$ prior to the laser pulse.

Photons at $\lambda=521 \mathrm{~nm}$ from the laser focal volume were recorded during two time gates: (i) Gate A: a $100 \mathrm{~ns}$ wide collection gate centred directly over the laser pulse to collect the LIF signal, laser scattered $\left(\sim 0.8-1 \mathrm{cts} \mathrm{s}^{-1} \mathrm{~mW}^{-1}\right)$ and solar scattered light (maximum $\sim 5 \mathrm{cts} \mathrm{s}^{-1}$ ) and (ii) Gate B: a $1000 \mathrm{~ns}$ wide collection gate, delayed $50 \mu$ s after the laser pulse to collect the signal due to solar scattered light and CPM dark counts (the latter $\sim 0.01 \mathrm{cts} \mathrm{s}^{-1}$ ). The difference in signal $\left(\mathrm{cts} \mathrm{s}^{-1}\right.$ ) between gates $\mathrm{A}$ and $\mathrm{B}$ is recorded as the $1 \mathrm{~s}$ averaged IO fluorescence signal and can be integrated to longer time periods as required. During all field measurements, a 1:1 duty cycle was adopted: the laser wavelength was tuned to the online wavelength $(444.887 \mathrm{~nm})$ for $60 \mathrm{~s}$, producing 60 one second online points (or 300000 laser shots), then tuned offline $(444.882 \mathrm{~nm})$ for $60 \mathrm{~s}$, producing 60 one second offline points. From these $1 \mathrm{~s}$ data (5000 laser shots), the data were usually averaged to generate a $1 \mathrm{~min}$ data point. The signals are normalised for laser power and the mean offline signal is subtracted from the mean online signal to give the laser normalised signal $\left(\mathrm{Sig}_{\mathrm{IO}}, \mathrm{cts} \mathrm{s}^{-1} \mathrm{~mW}^{-1}\right)$. Finally, this signal is divided by the sensitivity to give the IO concentration ([IO], molecule $\mathrm{cm}^{-3}$ ):

$[\mathrm{IO}]=\frac{\operatorname{Sig}_{\mathrm{IO}}}{C_{\mathrm{IO}}}$

where $C_{\mathrm{IO}}$ is the instrument sensitivity to IO $\left(\right.$ cts s$^{-1} \mathrm{~mW}^{-1}$ molecule ${ }^{-1} \mathrm{~cm}^{3}$ ). Using the ambient temperature and pressure recorded during the IO measurement period, the IO mixing ratio was then calculated.

\subsubsection{IO calibration}

Laser-induced fluorescence spectroscopy is not an absolute technique and the sensitivity of the instrument to IO must be determined by calibration. A turbulent-flow calibration system was developed to produce known concentrations of IO from the photolysis of a known concentration of $\mathrm{N}_{2} \mathrm{O}$ in the presence of excess $\mathrm{CF}_{3} \mathrm{I}$. The turbulentflow method is described in (Whalley et al., 2007), where a comparison with a laminar-flow calibration method found an agreement within the combined uncertainty of both methods. The sensitivity of the instrument was not found to vary throughout the measurement period and a sensitivity of $0.039( \pm 0.001) \mathrm{cts} \mathrm{s}^{-1} \mathrm{~mW}^{-1} \mathrm{pptv}^{-1}$ was used for all data analysis.

In the photolysis region, the concentration of IO is given by:

$[\mathrm{IO}]=\left[\mathrm{N}_{2} \mathrm{O}\right] \sigma_{\mathrm{N}_{2} \mathrm{O}} \phi_{\mathrm{IO}} \Omega F_{184.9 \mathrm{~nm}} \partial t$

where $\sigma_{\mathrm{N}_{2} \mathrm{O}}$ is the absorption cross-section of $\mathrm{N}_{2} \mathrm{O} \quad$ at $184.9 \quad \mathrm{~nm} \quad\left(\sigma_{\mathrm{N}_{2} \mathrm{O}}=1.43 \times\right.$ $10^{-19} \mathrm{~cm}^{2}$ molecule ${ }^{-1}$, Sander etal., 2006), $\phi_{\mathrm{IO}}$ is the chemical yield of $\mathrm{IO}$ from the reaction of $\mathrm{O}\left({ }^{3} \mathrm{P}\right)$ and $\mathrm{CF}_{3} \mathrm{I}$ $\left(\phi_{\mathrm{IO}}=0.83\right.$, Gilles et al., 1996), $F_{184.9 \mathrm{~nm}}$ is the photon flux of the lamp at $\lambda=184.9 \mathrm{~nm}$ and $\partial t$ is the irradiation time. The product $F_{184.9 \mathrm{~nm}} \partial t$ is determined by $\mathrm{N}_{2} \mathrm{O}$ actinometry (described in detail in Commane et al., 2010). Figure 2 shows a calibration over a range of ambient concentrations from $2.2 \mathrm{pptv}\left(5.4 \times 10^{7}\right.$ molecule $\left.\mathrm{cm}^{-3}\right)$ to $37.2 \mathrm{pptv}$ 
$\left(9.2 \times 10^{8}\right.$ molecule $\left.\mathrm{cm}^{-3}\right)$, which can be generated by varying both $\left[\mathrm{N}_{2} \mathrm{O}\right]\left(1.2-8 \times 10^{16}\right.$ molecule $\left.\mathrm{cm}^{-3}\right)$ and the lamp flux at $\lambda=189 \mathrm{~nm}\left(9.5 \times 10^{12}-2.5 \times 10^{13}\right.$ photon $\left.\mathrm{cm}^{-2} \mathrm{~s}^{-1}\right)$.

The total uncertainty in the IO calibration was found to be $23.5 \%$ at $1 \sigma$. This is the sum in quadrature of the uncertainty in the laser power (1\%), the lamp flux (11\%), the absorption cross-section of $\mathrm{N}_{2} \mathrm{O}(<1 \%)$, the chemical yield of IO from the reaction of $\left.\mathrm{O}^{3} \mathrm{P}\right)+\mathrm{CF}_{3} \mathrm{I}(11 \%)$, the concentration of $\mathrm{N}_{2} \mathrm{O}(1 \%)$ and the reproducibility of the wavemeter to accurately find the excitation wavelength of IO $(18 \%)$, which was determined from experimental tests with a constant calibration source.

The limit of detection (LOD) of the instrument is determined by both the sensitivity to $\mathrm{IO}\left(C_{\mathrm{IO}}\right)$ and the instrumental noise. For equal online and offline sample sizes with equal variance, the minimum detectable IO signal, IOSig ${ }_{\min }$, for a given confidence interval $(\mathrm{CI})$ can be calculated:

$\mathrm{IOSig}_{\min }=T_{\mathrm{CI}} \sqrt{\frac{2}{m}} \sigma_{\mathrm{IO}}$

where $T_{\mathrm{CI}}$ is the $T$ value for a given confidence interval $\left(T_{95} \%=2\right), m$ is the sample size defined by the sampling frequency and $\sigma_{\mathrm{IO}}$ is the standard deviation of the background, which is assumed to be representative of the standard deviation of the online sample. Assuming the background signal obeys Poisson Statistics (Whalley et al., 2007), the standard deviation of the total background signal is defined as the square root of the mean:

$\sigma_{\mathrm{IO}}=\sqrt{\left(S_{\mathrm{lb}}+S_{\mathrm{sb}}+S_{\mathrm{dc}}\right)}$

where $S_{\mathrm{lb}}$ is the signal due to laser scatter, $S_{\mathrm{sb}}$ is the signal due to solar background and $S_{\mathrm{dc}}$ are the dark counts of the CPM and $S_{\mathrm{lb}}+S_{\mathrm{sb}}+S_{\mathrm{dc}}$ is the mean of the sum of these $\left(S_{\mathrm{BG}}\right)$. For a $60 \mathrm{~s}$ measurement cycle at noon on 29 August, the limit of detection was calculated to be $1.25 \mathrm{pptv}$ (composed of $T_{95} \%=2, P_{\mathrm{IO}}=44.8 \mathrm{~mW}$, $C_{\mathrm{IO}}=0.039 \mathrm{cts} \mathrm{s}^{-1} \mathrm{~mW}^{-1} \mathrm{pptv}^{-1}, S_{\mathrm{BG}}=35.7 \mathrm{cts} \mathrm{s}^{-1}$, Solar Signal $=1.8 \mathrm{cts} \mathrm{s}^{-1}, m=60$ ).

$\mathrm{IOSig}_{\min }$ is converted into a minimum detectable mixing ratio of IO (pptv) by:

$\mathrm{IO}_{\min }=\frac{\mathrm{IOSig}_{\min }}{C_{\mathrm{IO}} P_{\mathrm{IO}}}$

where $C_{\mathrm{IO}}$ is the instrument sensitivity to IO (cts s${ }^{-1} \mathrm{~mW}^{-1} \mathrm{pptv}^{-1}$ ) and $P_{\mathrm{IO}}$ is the laser power in the IO cell $(\mathrm{mW})$.

\subsubsection{Influence of $\mathrm{NO}_{2}$}

$\mathrm{NO}_{2}$ exhibits a pressure-broadened absorption spectrum in the wavelength range used for IO excitation $(\lambda=444$ $445 \mathrm{~nm}$ ) and fluorescence from $\mathrm{NO}_{2}$ excited in this region includes the wavelength region transmitted through the bandpass interference filter $(\lambda=521 \mathrm{~nm})$. Tests were conducted on the instrument to determine the effect of $\mathrm{NO}_{2}$. It was found that no response in signal above the calculated instrumental LOD was observed for $\mathrm{NO}_{2}$ mixing ratios below $500 \mathrm{ppbv}$, which is far less than the sub-ppbv levels of $\mathrm{NO}_{2}$ observed at clean marine sites. With the addition of over $500 \mathrm{ppbv} \mathrm{NO}_{2}$, the instrument recorded a response of -0.004 pptv of false IO per ppbv of $\mathrm{NO}_{2}$, again much less than the instrument uncertainty. Thus, any interference from constant background $\mathrm{NO}_{2}$ mixing ratios would result in only a small underestimate of IO recorded.

\section{Point observations of IO}

Point observations of IO were made over eight days in August 2007 and encompassed diel cycles of high and low tides. The data were collected at $1 \mathrm{~s}$ (limit of detection $\sim 10 \mathrm{pptv}$ ) and averaged to $60 \mathrm{~s}$ (LOD $\sim 1-2 \mathrm{pptv}$ ). The high limit of detection associated with the $1 \mathrm{~s}$ data precludes the use of the $1 \mathrm{~s}$ data at all but the highest mixing ratios. In order for the entire diel/tidal cycle to be considered, the data were averaged to $60 \mathrm{~s}$. For comparison of the LP-DOAS and LIF IO data, both datasets were averaged to a common time basis, therefore the LIF data in Sect. 4 is averaged over $10 \mathrm{~min}$.

Figure 3 shows the observed time series of the IO mixing ratio (pptv) for $60 \mathrm{~s}$ time integration, where the IO mixing ratio showed a strong dependance on tide height. The highest IO mixing ratio of 29.3 pptv $(60 \mathrm{~s})$ was observed at low spring tide around noon on 29 August (spring tide; tidal height range of $4.5 \mathrm{~m}$ over $24 \mathrm{~h}$ ). At the neap tide (tidal height range of $1 \mathrm{~m}$ in $24 \mathrm{~h}$ ), a maximum IO mixing ratio of $4 \mathrm{pptv}$ was observed. The lowest neap tides occurred at dawn and dusk so the photolysis rate of photolabile sources of I atoms will be significantly lower than at mid-day and result in reduced I atom production. It is possible, and indeed probable, that neap tides at mid-day would result in greater IO mixing ratios than observed here.

\subsection{Temporal variability of IO}

Figure 4a shows a short section of IO data (over $2 \mathrm{~min}$ ) recorded at $1 \mathrm{~s}$ resolution close to low tide with both online and background signal (also recorded at $1 \mathrm{~s}$ resolution). Up to 49.7 ( \pm 8.6 ) pptv of IO was observed over a $1 \mathrm{~s}$ integration time at the lowest tide on 29 August, the highest mixing ratio of IO observed at Mace Head to date. Within this $60 \mathrm{~s}$ measurement period, the online IO mixing ratio (red) varies between $10.0 \mathrm{pptv}$ and $49.7 \mathrm{pptv}$. The variation in the offline signal (cts s ${ }^{-1}$; black) illustrates the range of instrumental variation expected (converted to an equivalent IO mixing ratio), which is much less than that observed in ambient observations. The offline signal is below the $1 \mathrm{~s}(2 \sigma)$ instrumental limit of detection (blue line) of $10 \mathrm{pptv}$.

Figure $4 \mathrm{~b}$ shows the $60 \mathrm{~s}$ data around spring tide with the standard deviation of the $1 \mathrm{~s}$ data within this mean shown as 

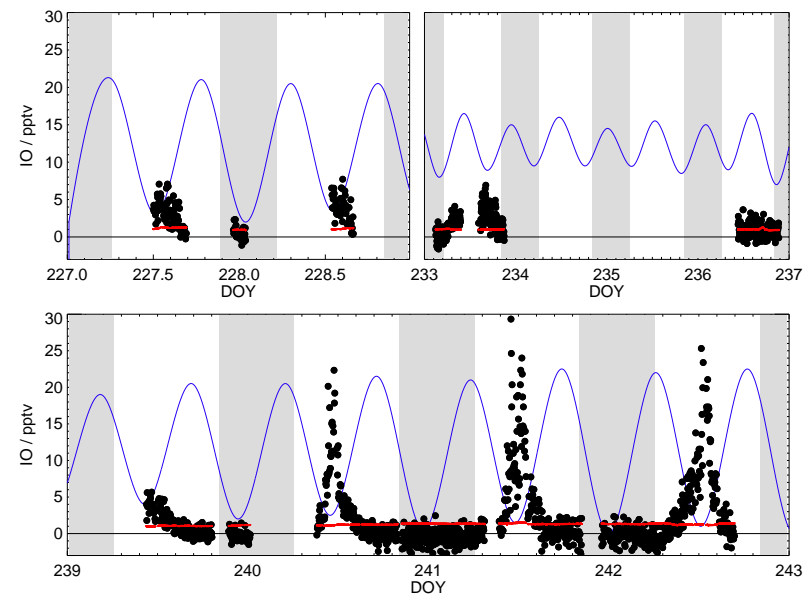

Fig. 3. IO mixing ratio (pptv) observed by LIF for a $60 \mathrm{~s}$ time integration period (black) for the Day of Year (DOY) in 2007; IO instrument $60 \mathrm{~s}$ limit of detection $(\sim 1.4 \mathrm{pptv}$ at $2 \sigma)$ (red); predicted tide height at Roundstone Bay (blue) scaled to fit the graph. Shaded areas indicate night-time observations. Data were collected between 15 (DOY 227) and 30 August (DOY 242) 2007.

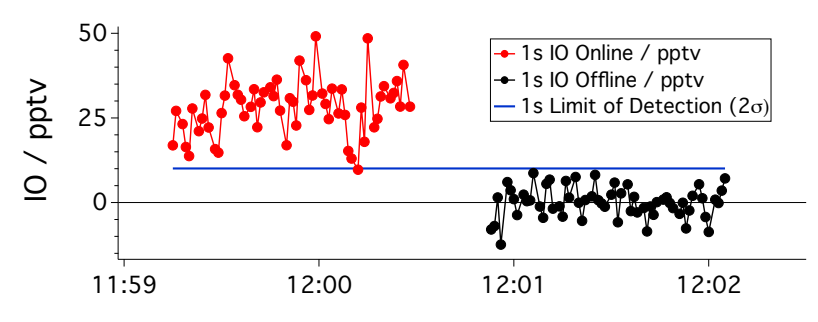

29 August 2007

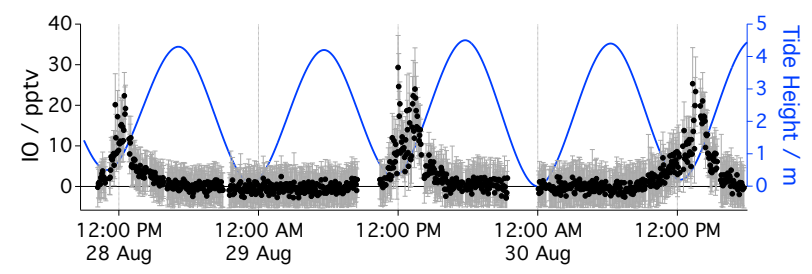

Fig. 4. (top) $1 \mathrm{~s}$ IO mixing ratio (pptv) (red) at noon on $29 \mathrm{Au}-$ gust (DOY 241) in 2007. The $1 \mathrm{~s}$ background signal converted to an equivalent IO mixing ratio is indicated as "offline" and shown in black. The $1 \mathrm{~s}$ limit of detection $(2 \sigma)$ shown in blue. Up to 49.7 ( \pm 8.6) pptv IO was observed over this short time scale. (bottom) $60 \mathrm{~s} \mathrm{IO} \mathrm{mixing} \mathrm{ratio} \mathrm{(pptv;} \mathrm{black)} \mathrm{with} \mathrm{the} \mathrm{standard} \mathrm{deviation}$ of the $1 \mathrm{~s}$ data within the $60 \mathrm{~s}$ block average shown as error bars (grey). Tide height is shown as a blue line.

$\mathrm{a} \pm$ error bar. The variability of the $1 \mathrm{~s}$ IO data at daytime low tide is much greater than during the night or high tide and suggests that the nearby macroalgae (a source of halocarbons and molecular iodine) are not steadily emitting IO precursor species, perhaps as a result of wave action or changing wind speeds.

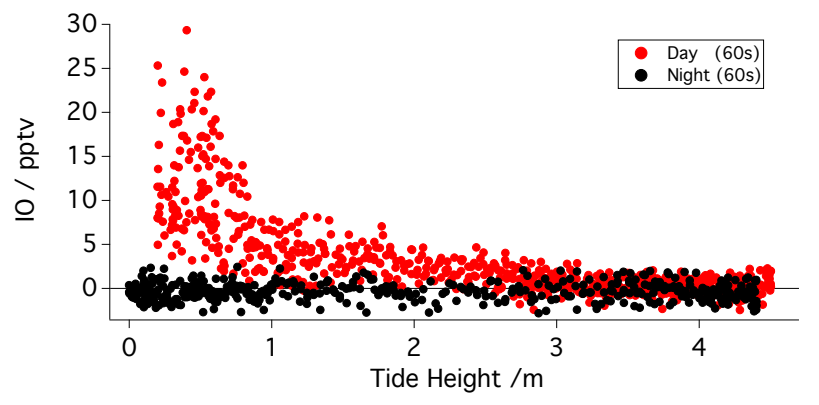

Fig. 5. IO mixing ratio observed by LIF ( $60 \mathrm{~s}$ integration time) against tide height: day (red), night (black). A clear anti-correlation of IO with tide height can be seen during daylight hours but there is no tidal dependance at night.

At mid-latitude coastal marine boundary layer sites, molecular iodine emission from macroalgae in the intertidal zone has previously been identified as a major source of IO (Saiz-Lopez and Plane, 2004; McFiggans et al., 2004). Küpper et al. (2008) propose that the ozone-scavenging reactivity of iodide on kelp surfaces at low tide leads to the direct release of molecular iodine from Laminaria into the coastal atmosphere. The emission of iodine from Laminaria has also been linked to dessication and physical agitation (Bale et al., 2008; Ball et al., 2010). The physical agitation caused by wave motion as the tide returns could contribute to the large variability seen in the $1 \mathrm{~s}$ IO data. However recent chamber studies have suggested iodine emission from Laminaria may also occur in cycles independently of physical agitation (Dixneuf et al., 2009), where the release of $I_{2}$ was found to occur in short, strong bursts with a complex time signature. Dixneuf et al. (2009) suggest that the time signature may be based on an autocatalytic reaction mechanism which is closely related to the production of $\mathrm{H}_{2} \mathrm{O}_{2}$ in the macroalgae.

At times of highest IO, macroalgae were located a maximum of $\sim 100 \mathrm{~m}$ upwind of the LIF sampling point and, with mean wind speeds of $\sim 5 \mathrm{~m} \mathrm{~s}^{-1}$ at this time, the mean chemical processing time between emission and sampling was $\sim 20 \mathrm{~s}$. This suggests that $I_{2}$ (with a photolysis lifetime of $10 \mathrm{~s}$ at mid-day) is the dominant source of I atoms and the major precursor to IO at Mace Head. However, with a prevailing westerly wind and wind speeds of $5-10 \mathrm{~m} \mathrm{~s}^{-1}$ typical in the area, it is possible that the maximum IO mixing ratio, greatest $\mathrm{O}_{3}$ destruction and peak in particle formation all occur inland from the observation point at Mace Head. The magnitude and location of this $\mathrm{O}_{3}$ destruction are discussed further in Sect. 4.3.2.

\subsection{Diel and tidal dependance of IO}

The tidal variation of IO shows two distinct modes associated with the diel cycle (Fig. 5). During the day, a clear anti-correlation of IO with tide height can be seen and the 


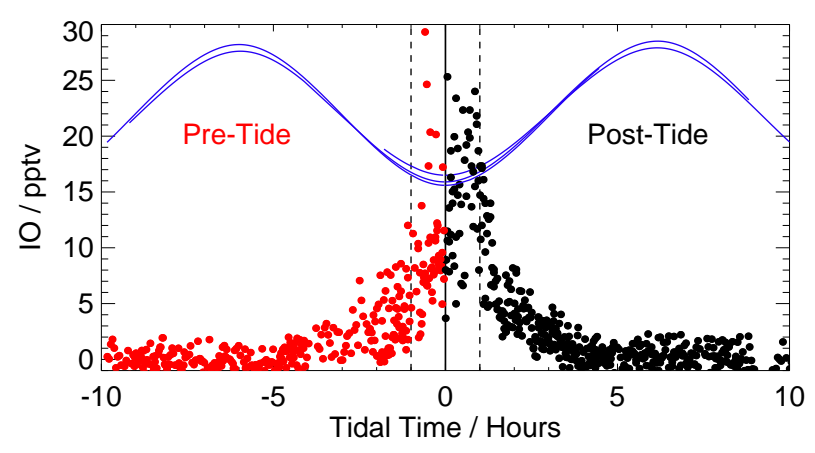

Fig. 6. IO mixing ratio as a function of time from daytime low tide for all data between 28-30 August. Data are separated between before (red) and after (black) daytime low tide. The hour before and after low tide is indicated by black dashed lines.

highest IO mixing ratios were observed around daytime low tide. These daytime data were highly variable on all days with IO mixing ratios between 3 and 29 pptv (60 s integration time) observed at low tide.

Seaweed surveys at Mace Head over various tide heights found that macroalgae are widely distributed in narrow tidal strips a few metres wide directly in front (and upwind) of the research station. A visual inspection of the area in front of the LIF observation point showed no macroalgae were exposed at tide heights greater than $\sim 3 \mathrm{~m}$ (high tide). The observed IO mixing ratios were of a similar range during day and night for these high tides heights. This suggest that any open ocean iodine sources were not sufficient to allow detection of IO at the LIF sampling point. At tide heights between 3 and $1 \mathrm{~m}$ macroalgae species such as Palmaria palmata, Ascophyllum nodosum and various type of Fucus were present and a maximum IO mixing ratio of $8.2 \mathrm{pptv}$ was observed during the day. At low tides below $1 \mathrm{~m}$, large beds of Laminaria digitata were exposed directly in front of the LIF sampling point and mixing ratios of IO up to $29.3 \mathrm{pptv}$ were observed (60 s integration period).

\subsubsection{Temporal offset from low tide}

Defining a common time basis based on hours from low tide (Tidal Time) allows the continuous $60 \mathrm{~s}$ IO data series on the final three days of measurements (as shown in Fig. 4b) to be considered together. Figure 6 shows the 60 s IO data on this common time basis. Overall the time of the IO enhancement (IO mixing ratios greater than the limit of detection) averages to about five hours around daytime low tide. Although the maximum observed IO occurred before low tide (29 August), overall the mean IO detected in the hour after low tide (13.7 pptv) is greater than before low tide ( $8.4 \mathrm{pptv})$ and most of the IO above 12 pptv (peak IO) is concentrated in the hour after low tide. The time delay between low tide and the peak IO observed here could be attributed to the time required for

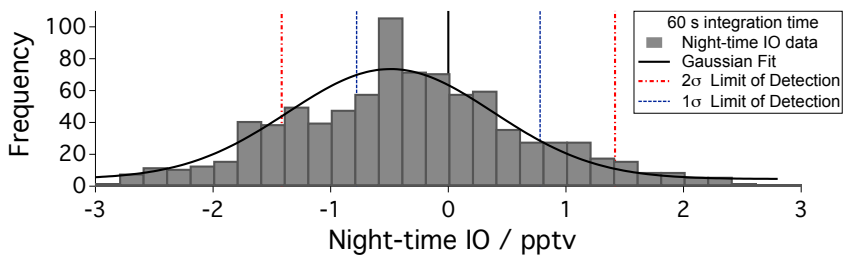

Fig. 7. Histogram of night-time IO data $(60 \mathrm{~s}$ integration time; grey boxes), \pm LOD $(2 \sigma=$ 1.4 pptv; red dash-dot lines, $1 \sigma=0.78$ pptv; blue dashed lines). A Gaussian fit to these data (black line) shows a slight negative bias $(-0.49$ pptv).

the Laminaria to dry out and emit $\mathrm{I}_{2}$, as suggested by laboratory studies of L. Digitata by Bale et al. (2008) and Ball et al. (2010).

The time delay between low tide and peak IO coincides with the sharp increase in sub- $10 \mathrm{~nm}$ particle number observed in the hour after low tide during the PARFORCE and BIOFLUX campaigns at Mace Head (O'Dowd and Hoffmann, 2005), suggesting IO plays a key role in new particle formation. Unfortunately, no aerosol measurements were made at Mace Head during the observation period of this study, which prevents direct comparison with the IO data.

IO mixing ratios of up to $50 \mathrm{pptv}(1 \mathrm{~s})$ are significantly greater than any spatially-averaged IO mixing ratio reported to date and provide further evidence of the role of IO in new particle formation. Modeling studies suggested that IO mixing ratios of the order of $50 \mathrm{pptv}$ would be required to explain new particle formation initiated by the IO self reaction (Burkholder et al., 2004), while Saunders et al. (2010) suggest the growth of particles proceeds through higher oxide polymerisation:

$$
\begin{aligned}
& \mathrm{IO}+\mathrm{IO} \stackrel{k_{6}}{\longrightarrow} \mathrm{OIO}+\mathrm{I} \\
& \mathrm{IO}+\mathrm{OIO} \stackrel{k_{7}}{\longrightarrow} \mathrm{I}_{2} \mathrm{O}_{3} \\
& \mathrm{I}_{2} \mathrm{O}_{3}+\mathrm{I}_{2} \mathrm{O}_{4} \longrightarrow \longrightarrow \text { NewParticleFormation }
\end{aligned}
$$

At Mace Head in 2004, Saiz-Lopez et al. (2006b) found that both $\mathrm{I}_{2}$ and ultra-fine aerosols peaked around low-tide, while in Mweenish Bay, $6 \mathrm{~km}$ south of Mace Head, Seitz et al. (2010) found that nucleation events coincided with peak IO. Each of these LP-DOAS instruments requires a (minimum) 10 minute integration time. In Roscoff, France, Furneaux etal. (2010) found that ultra fine particles were generally observed around the same time as the highest IO mixing ratios but that the peak IO mixing ratios showed a temporally broader peak.

\subsubsection{Night-time IO}

At night, there is no tidal dependance evident in the IO mixing ratios. Figure 7 shows the probability distribution of the IO mixing ratio observed at night. The observations are 
distributed around zero, within the mean instrumental limit of detection $(2 \sigma)$, with a slight negative bias $(-0.49 \mathrm{pptv})$. Previous observations of IO at night at Mace Head were associated with high $\mathrm{NO}_{3}$ mixing ratios (Saiz-Lopez et al., 2006a) and the only known IO production pathway at night is through the reaction of $\mathrm{I}_{2}$ with $\mathrm{NO}_{3}$ :

$$
\begin{gathered}
\mathrm{I}_{2}+\mathrm{NO}_{3} \stackrel{k_{9}}{\longrightarrow} \mathrm{IONO}_{2}+\mathrm{I} \\
\mathrm{I}+\mathrm{O}_{3} \stackrel{k_{10}}{\longrightarrow} \mathrm{IO}+\mathrm{O}_{2}
\end{gathered}
$$

where $\quad k_{9}=1.5 \times 10^{-12} \mathrm{~cm}^{3}$ molecule ${ }^{-1} \mathrm{~s}^{-1}$, (Chambers et al., 1992) and $k_{10}=1.2 \times$ $10^{-12} \mathrm{~cm}^{3}$ molecule ${ }^{-1} \mathrm{~s}^{-1}$ at $298 \mathrm{~K}$ (Sander et al., 2006).

During the LIF measurement period, mixing ratios of $\mathrm{NO}_{3}$ were found to be below the LP-DOAS limit of detection of 4.8 pptv, while a maximum $\mathrm{I}_{2}$ mixing ratio of 65 pptv was observed at night by LP-DOAS. Saiz-Lopez et al. (2006b) showed that the spatially-averaged $\mathrm{I}_{2}$ observed by LP-DOAS was concentrated in a short distance over the inter-tidal area and mixing ratios of greater than $65 \mathrm{pptv}$ are probable and up to 100 pptv $I_{2}$ is possible (Bitter et al., 2005). Given typical ozone mixing ratios of $\sim 30 \mathrm{ppbv}$, an upper limit of 4.8 pptv of $\mathrm{NO}_{3}$ and an estimated 200 ppt of $\mathrm{I}_{2}$, the IO formation rate is about $0.03 \mathrm{pptv} \mathrm{s}^{-1}$, neglecting all IO removal processes. This requires a minimum of $40 \mathrm{~s}$ to form sufficient IO for detection by the LIF instrument ( $2 \sigma$ LIF limit of detection $=1.46 \mathrm{pptv}$ ). With windspeeds of $5-10 \mathrm{~m} \mathrm{~s}^{-1}$ at the site, the transit time of air passing between the macroalgae exposed at low tide to the LIF sampling point is between 10 and $20 \mathrm{~s}$, which is insufficient time for detectable mixing ratios of IO to be formed at night.

\section{Comparison of spatially-averaged and point observations of IO}

For three days around low tide at Mace Head, IO was measured by a long-path Differential Optical Absorption Spectroscopy (LP-DOAS) instrument from the University of Heidelberg (Huang et al., 2010). The wind was consistently arriving at the site from the west to north-west for all three days, allowing direct comparison of spatially-averaged and point measurements of IO.

\subsection{Long path - DOAS instrument}

Differential Optical Absorption Spectroscopy (DOAS) (Platt and Stutz, 2008) is a well established technique to identify and quantify trace gases by their narrow band absorption structures. The setup of the active long-path DOAS (LP-DOAS) systems used was a further development of the coaxial mirror system introduced by Axelson et al. (1990). A detailed description of the Fibre LP-DOAS can be found in Merten etal. (2011). The light path ( $6.8 \mathrm{~km}$ one-way) crossed Roundstone Bay to Roundstone about $10 \mathrm{~m}$ above sea level at high tide (Fig. 1), where a retro-reflector consisting of 76 quartz prisms $(63 \mathrm{~mm}$ diameter) was located. The reflected light was diffracted by a spectrometer (Acton Spectra Pro 300, $f=4.1,1900 \mathrm{gr} \mathrm{mm}^{-1}$ ). The detector used was a 1024 pixel photodiode array detector (type Hamamatsu S3904-1024). IO was measured in the $416-439 \mathrm{~nm}$ wavelength range, with a $10 \mathrm{~min}$ integration time. For the analysis the software DOASIS (Kraus, 2005) was used to simultaneously fit the different references to the atmospheric spectrum using a non-linear least-squares method (e.g., Stutz and Platt, 1996). In addition, a polynomial of 5th order was included to account for broad band structures due to scattering in the atmosphere. As well as the IO cross section (Gómez Martín et al., 2005; Spietz et al., 2005), references of $\mathrm{NO}_{2}$ (Voigt et al., 2002), and $\mathrm{H}_{2} \mathrm{O}$ vapour (Rothman et al., 2005) were included in the fitting procedure. $\mathrm{NO}_{3}$ was analysed between 618 and $626 \mathrm{~nm}$ and 657 and $664 \mathrm{~nm}$ and fitted using $\mathrm{NO}_{3}$ (Yokelson et al., 1994) and $\mathrm{H}_{2} \mathrm{O}$ vapour cross sections. Over the three days discussed here, $\mathrm{NO}_{3}$ mixing ratios were not observed above the detection limit of $4.8 \mathrm{pptv}$. $\mathrm{I}_{2}$ was fitted between 510 and $590 \mathrm{~nm}$ (Saiz-Lopez and Plane, 2004), with mixing ratios up to $65 \mathrm{pptv}$ detected on the single night of $\mathrm{I}_{2}$ measurements made during the intercomparison period.

\subsection{Inhomogeneities in IO distribution}

Figure 8 shows the time series of both the LIF and LP-DOAS IO mixing ratios. The general trend of higher IO at daytime low tide is reproduced by both instruments but the in situ LIF IO mixing ratios are much greater than the spatially averaged LP-DOAS IO mixing ratios. Over the LP-DOAS 10 min integration time, the maximum IO measured by LP-DOAS was 4.4 pptv, compared to the 22 pptv IO observed by the LIF instrument over the same time period. The presence of shortlived bursts of high IO mixing ratios evident in the $1 \mathrm{~s}$ and $60 \mathrm{~s}$ LIF time series may be sufficient to initiate new particle formation but these high mixing ratios are masked by the long integration time required by the LP-DOAS instrument.

The ratio of IO point measurements to spatially averaged measurements indicates the extent of the spatial distribution throughout the DOAS light beam. While the peak LIF IO mixing ratio was above $20 \mathrm{pptv}$ on all the comparison days, the peak DOAS IO mixing ratios steadily increased from 2 pptv to 4 pptv over the course of the three days, resulting in the LIF/LP-DOAS ratio changing as the tidal structure changed. An increase in IO at low tides is present in the spatially averaged LP-DOAS observations but to much less of an extent than that seen in the point observations. Figure 8c shows the anti-correlation of the LIF/LP-DOAS ratio with tide height. On 28-29 August, the maximum ratio reaches 9.8. Back-trajectory analysis shows the air arriving at the site on these days was north-westerly and had passed over coastal areas to the west of Roundstone. A seaweed survey conducted by the Irish Seaweed Centre at National University of Ireland, Galway shows the presence of extensive beds of Laminaria digitata and L. hyperborea along this coastline 

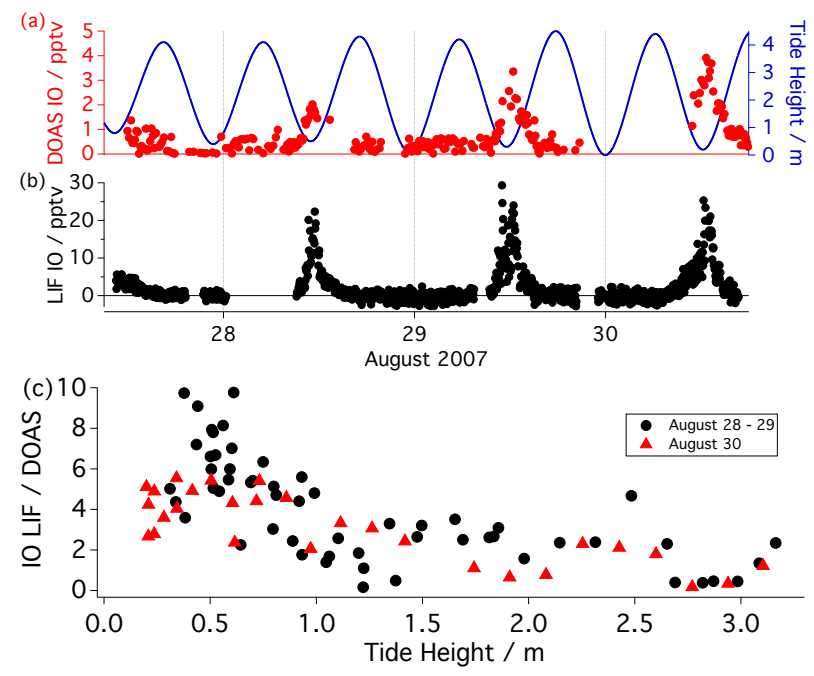

Fig. 8. Observation of LP-DOAS and LIF IO between 28-30 August. (a) LP-DOAS IO (pptv, red, $10 \mathrm{~min}$ ), tide height (blue), (b) LIF IO (pptv, black, 1 min), (c) anti-correlation of the LIF/LPDOAS IO ratio with tide height down to $0.3 \mathrm{~m}$. 30 August (red triangles) shows a lower ratio than 28-29 August (black dots). This corresponds to increased IO detected by the LP-DOAS on $30 \mathrm{Au}-$ gust.

to the west of Inishlackan (the island south of Roundstone, shown in detail in Fig. 1).

On 30 August, the ratio reaches a maximum of 5.5 and coincides with the highest IO observed by LP-DOAS. Back-trajectory analysis showed the wind arrived from a more westerly direction on 30 August but the wind direction did not vary throughout the day. Measurements of wind direction at a nearby meteorology station confirmed the constant wind direction. Consequently there is the less influence from the macroalgae to the north-west of the site and air spent less time traveling over the macroalgae beds directly in front of the site before being sampled by the LIF instrument on 30 August compared to 28 and 29 August. On $30 \mathrm{Au}-$ gust, the LIF/LP-DOAS ratio decreases with tide heights below $\sim 0.3 \mathrm{~m}$. At these tide heights additional Laminaria was also exposed at the retro-reflector end of the LP-DOAS light path, as well as at the edges of two islands close to the light path, that had not been exposed for any significant time on previous days. This increased inhomogeneity in IO sources may account for the increase in the LP-DOAS mixing ratio (compared to the LIF mixing ratio) observed below these tide heights on 30 August.

The point observations of IO presented in this study provide the first direct experimental evidence of the extent of the spatial inhomogeneity of IO along the DOAS light path at Mace Head. This observation agrees with Seitz et al. (2010), who found inhomogeneities in IO at Mweenish Bay ( $6 \mathrm{~km}$ south of Mace Head). Similar IO column densities were observed for path-lengths of 1034 and $3946 \mathrm{~m}$ over the intertidal area and directly over beds of macroalgae. A peak mixing ratio of $29 \mathrm{pptv}(10 \mathrm{~min})$ was observed in the short path over the intertidal area. Another study at Roscoff, France found point observations of IO were only a factor of 2-3 higher than spatially averaged IO (Furneaux et al., 2010; Wada et al., 2007), suggesting that inhomogeneities in IO distributions are location specific.

Indirect evidence of inhomogeneities in IO have been observed at coastal sites previously. Comparison of spatially averaged $\mathrm{I}_{2}$ observed by LP-DOAS and point measurements by cavity ring-down spectroscopy (CRDS) (SaizLopez et al., 2006b) and a denuder technique (Huang et al., 2010) have highlighted the inhomogeneity in the iodine distribution along the LP-DOAS light path at Mace Head. Model calculations by Saiz-Lopez et al. (2006b) suggested that all the $\mathrm{I}_{2}$ was located in a narrow coastal band of less than $10 \%$ of the total light-path. Due to a lack of point observations of IO at that time, it was not possible to prove this hypothesis for IO, but local IO mixing ratios of up to $47 \mathrm{pptv}$ were suggested from the $\mathrm{I}_{2} / \mathrm{IO}$ ratio observed by LP-DOAS. This predicted inhomogeneity is in good agreement with the point observations of IO presented here.

\subsection{Implications of inhomogeneities in IO}

The presence of high concentrations of iodine monoxide leads to a number of effects on the local chemistry, including oxidative capacity and the potential for new particle formation.

\subsubsection{Evolution of IO with tide height}

The daytime point observations of IO by LIF were found to be anti-correlated with tide and can be quantified as:

$\mathrm{IO}=17.75 \mathrm{e}^{-\mathrm{TH} / 1.08}+0.02$,

where IO is in pptv and TH is tide height in metres. This is a stronger correlation with tide height than seen previously at Mace Head. The LP-DOAS light beam sampled over ocean for more than $90 \%$ of the light path so a weaker correlation of IO with tide height is expected. Figure 9 shows how a relationship of $\mathrm{IO}=3.07 \mathrm{e}^{-\mathrm{TH} / 1.29}+0.44$ observed by the LP-DOAS during this study compares to a previous study by Carpenter et al. (2001), which found a exponential correlation of $\mathrm{IO}=2.6 \mathrm{e}^{-\mathrm{TH} / 1.7}$. The LP-DOAS path-length during Carpenter et al. (2001) was $14.6 \mathrm{~km}$ compared to the LPDOAS path-length of $13.6 \mathrm{~km}$ used here, resulting in greater spatial averaging in the Carpenter et al. (2001) study. Both paths were to Roundstone to the north of Mace Head. It is probable that the high mixing ratios of IO observed by the LIF instrument here were previously masked by both the long time $(30 \mathrm{~min})$ and spatial averaging $(14 \mathrm{~km})$ of LP-DOAS measurements.

At a semi-polluted site in Roscoff, Northern France, Furneaux et al. (2010) found that point measurements of IO 


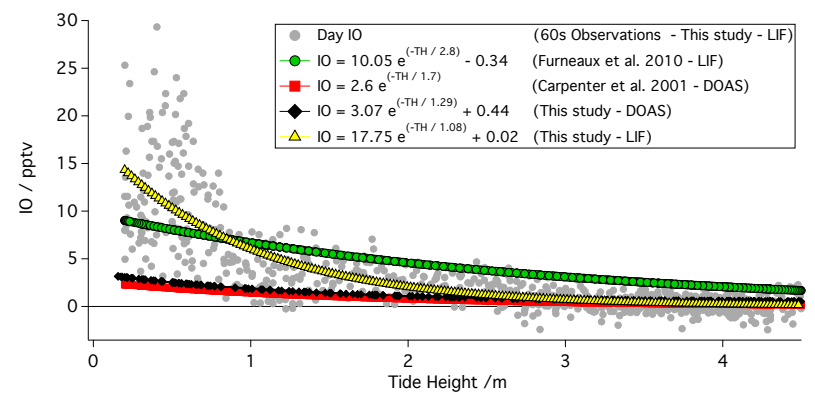

Fig. 9. IO as a function of tide compared to other studies. Point observations of IO by LIF presented in this study (one minute data: grey points, tidal dependance: yellow triangles), Furneaux et al. (2010) point observations by LIF at Roscoff, France (green points), Carpenter et al. (2001) LP-DOAS observations at Mace Head (red squares), LP-DOAS observations from this study (black diamonds). Point observations of IO (by LIF) show the strongest dependance on tide height.

by LIF were only a factor of 2-3 greater than spatially averaged LP-DOAS measurements. The IO by LIF relationship with tide was determined to be $\mathrm{IO}=10.05 \mathrm{e}^{-\mathrm{TH} / 2.8}-0.34$. This slightly weaker correlation than observed by LIF at Mace Head may be due to the more dispersed sources of $\mathrm{IO}$ and the titration of IO by the higher $\mathrm{NO}_{\mathrm{x}}$ mixing ratios present at Roscoff. IO may also have been chemically consumed or lost to new particle formation during the long transit time between the widely dispersed macroalgae and the sampling point.

\subsubsection{Impact on oxidation}

During the day, $\mathrm{O}_{3}$ is photolysed to form $\mathrm{O}\left({ }^{1} \mathrm{D}\right)$ (leading to $\mathrm{OH}$ formation). $\mathrm{O}_{3}$ can also be destroyed by reaction with I atoms to form IO. The self-reaction of IO produces OIO and I atoms, alongside other products, and the produced I atoms then react with $\mathrm{O}_{3}$ to reform $\mathrm{IO}$, resulting in the iodine induced catalytic destruction of ozone:

$$
\begin{array}{r}
\mathrm{I}+\mathrm{O}_{3} \stackrel{k_{12}}{\longrightarrow} \mathrm{IO}+\mathrm{O}_{2} \\
\mathrm{IO}+\mathrm{IO} \stackrel{k_{13}}{\longrightarrow} \mathrm{OIO}+\mathrm{I}
\end{array}
$$

where $k_{12}=2.3 \times 10^{-11} \exp (-870 / T)$ (Sander et al., 2006) and $k_{13}=\phi_{O I O} 5.4 \times 10^{-11} \exp (180 / T)$ (Atkinson etal., 2007), (branching ratio, $\phi_{\mathrm{OIO}}=0.38$, Bloss et al., 2001). The combination of these processes may explain the $5 \mathrm{ppbv}$ reduction in ozone observed around low tide on 30 August 2007 (Fig. 10), although physical process such as ozone deposition may also contribute to ozone loss at low tide (Whitehead et al., 2009).

It is unlikely that the macroalgae located within $10-20 \mathrm{~s}$ transport time of the sampling cell was the source of ozonedepleting iodine, as the reaction of $\mathrm{O}_{3}$ with $\mathrm{I}$ atoms to produce $\mathrm{IO}$ is too slow for $\mathrm{O}_{3}$ to be appreciably depleted within

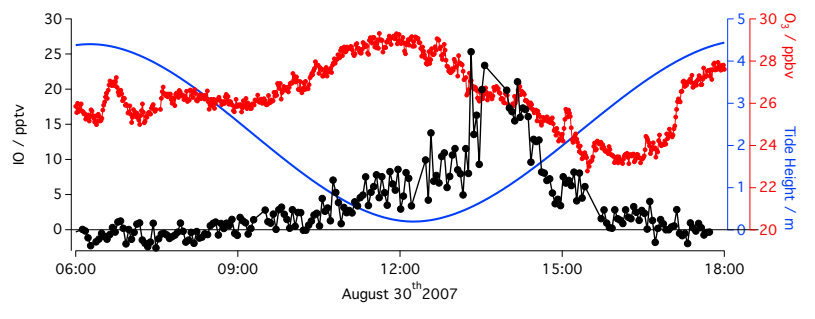

Fig. 10. Time series of $\mathrm{IO}$ and $\mathrm{O}_{3}(60 \mathrm{~s})$ and tidal height $(\mathrm{m})$ for 30 August, 2007.

this time. Up to 22 pptv of I atoms was observed at low tide during the measurement period (Bale et al., 2008). In the presence of $28 \mathrm{ppbv} \mathrm{O}_{3}, 22 \mathrm{pptv}$ of I atoms will result in the loss of $0.08 \mathrm{ppbv} \mathrm{O}_{3}$ in $20 \mathrm{~s}$. In fact, simply considering these reactions, a minimum processing time of 20 minutes would be required to account for the 5 ppbv $\mathrm{O}_{3}$ depletion observed and suggests an iodine source region located $6-12 \mathrm{~km}$ to the west/north-west depending on wind speed.

For the $50 \mathrm{pptv}$ of IO observed at the site at low tide (linked to the emission of iodine from macroalgae directly in front of the observation point), $\mathrm{O}_{3}$ destruction is likely to take place significantly downwind and, given the wind direction, inland from the site. Again, assuming purely chemical loss of $\mathrm{O}_{3}$ through reaction with $\mathrm{I}$ atoms, between $0.3 \mathrm{ppbv}$ and $0.6 \mathrm{ppbv} \mathrm{O}_{3}$ will be lost within $1 \mathrm{~km}$ of the coast. However, this calculation does not account for IO loss to new particle formation, other sinks or dilution effects and should be treated as an upper limit for $\mathrm{O}_{3}$ chemical loss.

Models of fast photochemistry at Mace Head have highlighted the impact of halogens on $\mathrm{HO}_{\mathrm{x}}$. Sommariva et al. (2006) used an in situ box model to show that observed $\mathrm{HO}_{2}$ could be reproduced by increasing the maximum spatiallyaveraged IO concentrations observed by an order of magnitude. In the presence of $50 \mathrm{ppt} \mathrm{IO}$, the modelled $\mathrm{HO}_{2}$ concentration was reduced by $50 \%$ and the modelled $\mathrm{OH}$ increased by $30 \%$, in close agreement with observed values. The formation (Reaction 14) and photolysis of HOI (Reaction 15):

$\mathrm{IO}+\mathrm{HO}_{2} \stackrel{k_{14}}{\longrightarrow} \mathrm{HOI}$
$\mathrm{HOI}+h v \stackrel{j_{15}}{\longrightarrow} \mathrm{OH}+\mathrm{I}$

was found to be the dominant $\mathrm{HO}_{2} \rightarrow \mathrm{OH}$ pathway, more than an order of magnitude greater than the normally dominant $\mathrm{HO}_{2}+\mathrm{NO} \rightarrow \mathrm{OH}+\mathrm{NO}_{2}$ pathway.

The point observations of IO presented here show that mixing ratios of IO greater than $10 \mathrm{pptv}$ are only present at tide heights below $1 \mathrm{~m}$. This suggests that iodine related chemistry dominates the $\mathrm{HO}_{\mathrm{x}}$ budget at Mace Head only during the low tide periods of spring tides. 


\section{Conclusions}

Point measurements of IO were made at Mace Head Atmospheric Research Station, a clean marine site on the west coast of Ireland. IO was found to be highly variable, with up to 49.8 pptv IO observed ( $1 \mathrm{~s})$. IO showed a strong anticorrelation with daytime low tide and the associated local macroalgae exposure. IO peaked in the hour after low tide, an offset which may be due to the time required for dessication and oxidative stressing of macroalgae, as well as mechanical agitation from returning waves. This is consistent with previous aerosol observations, which saw a peak in $<10 \mathrm{~nm}$ particle number in the hour after low tide. No IO mixing ratios above the instrumental limit of detection were observed at night.

A comparison of spatially-averaged long-path Differential Optical Absorption Spectroscopy (LP-DOAS) observations of IO with point observations of IO by LIF showed similar temporal trends. However LP-DOAS reported a factor of between 6 and 10 times less than the LIF observations of IO, consistent with the assumption of inhomogeneities of IO along the LP-DOAS light-path used to explain previous radical point measurements.

Overall the observations presented here found that coastal areas influenced by macroalgae contain high concentrations of IO but only for short periods of time (daytime low tide). While these high concentrations of IO may significantly perturb local oxidation chemistry, this large effect will be relatively short-lived.

Acknowledgements. The authors would like to thank the staff at the Mace Head Atmospheric Research Station and NUI Galway, in particular G. Jennings and G. Spain. Meteorological and supporting measurements were provided by G. Spain (University of Bristol) and B. Kelly (NUIG/Met Éireann). Support for access to Mace Head was given by the European Community - Research Infrastructure Action under EUSAAR TNA programme. The LP-DOAS deployment was conducted under the MAP Project funded by the European Commission (under FP6 project number 018332). Tidal data reproduced by permission of the Controller of Her Majesty's Stationery Office and the UK Hydrographic Office (www.ukho.gov.uk). We would like to thank Stefan Kraan from the Irish Seaweed Center for providing seaweed maps. We are grateful for the expert technical support from the workshops in the School of Chemistry at the University of Leeds.

Edited by: A. Hofzumahaus

\section{References}

Alicke, B., Hebestreit, K., Stutz, J., and Platt, U.: Iodine oxide in the marine boundary layer, Nature, 397, 572-573, 1999.

Atkinson, R., Baulch, D. L., Cox, R. A., Crowley, J. N., Hampson, R. F., Hynes, R. G., Jenkin, M. E., Rossi, M. J., and Troe, J.: Evaluated kinetic and photochemical data for atmospheric chemistry: Volume III - gas phase reactions of inorganic halogens, At- mos. Chem. Phys., 7, 981-1191, doi:10.5194/acp-7-981-2007, 2007.

Axelson, H., Galle, B., Gustavson, K., Ragnarsson, P., and Rudin, M.: A transmitting and receiving telescope for DOASmeasurements using retroreflektor technique, Techn. Dig. S., 4, 641-644, 1990.

Bale, C. S. E., Ingham, T., Commane, R., Heard, D. E., and Bloss, W. J.: Novel measurements of atmospheric iodine species by resonance fluorescence, J. Atmos. Chem., 60, 5170, doi:10.1007/s10874-008-9108-z, http://www.springerlink. com/content/k6j323266406772j, 2008.

Ball, S. M., Hollingsworth, A. M., Humbles, J., Leblanc, C., Potin, P., and McFiggans, G.: Spectroscopic studies of molecular iodine emitted into the gas phase by seaweed, Atmos. Chem. Phys., 10, 6237-6254, doi:10.5194/acp-10-6237-2010, 2010.

Bitter, M., Ball, S. M., Povey, I. M., and Jones, R. L.: A broadband cavity ringdown spectrometer for in-situ measurements of atmospheric trace gases, Atmos. Chem. Phys., 5, 2547-2560, doi:10.5194/acp-5-2547-2005, 2005.

Bloss, W. J., Rowley, D. M., Cox, R. A. and Jones, R. L.: Kinetics and products of the IO self-reaction, J. Phys. Chem. A, 105, 7840-7854, 2001.

Bloss, W. J., Lee, J. D., Johnson, G. P., Sommariva, R., Heard, D. E., Saiz-Lopez, A., Plane, J. M. C., McFiggans, G., Coe, H., Flynn, M., Williams, P., Rickard, A. R., and Fleming, Z. L.: Impact of halogen monoxide chemistry upon boundary layer $\mathrm{OH}$ and $\mathrm{HO}_{2}$ concentrations at a coastal site, Geophys. Res. Lett., 32, L06814, doi:10.1029/2004GL022084, 2005.

Burkholder, J. B., Curtius, J., Ravishankara, A. R., and Lovejoy, E. R.: Laboratory studies of the homogeneous nucleation of iodine oxides, Atmos. Chem. Phys., 4, 19-34, doi:10.5194/acp-4-192004, 2004.

Carpenter, L. J., Hebestreit, K., Platt, U., and Liss, P. S.: Coastal zone production of IO precursors: a 2-dimensional study, Atmos. Chem. Phys., 1, 9-18, doi:10.5194/acp-1-9-2001, 2001.

Chambers, R. M., Heard, A. C., and Wayne, R. P.: Inorganic gasphase reactions of the nitrate radical: iodine + nitrate radical and iodine atom + nitrate radical, J. Phys. Chem., 96, 3321-3331, doi:10.1021/j100187a028, 1992.

Commane, R., Floquet, C. F. A., Ingham, T., Stone, D., Evans, M. J., and Heard, D. E.: Observations of $\mathrm{OH}$ and $\mathrm{HO}_{2}$ radicals over West Africa, Atmos. Chem. Phys., 10, 8783-8801, doi:10.5194/acp-10-8783-2010, 2010.

Davis, D., Crawford, J., Liu, S., McKeen, S., Bandy, A., Rowland, D. T. F., and Blake, D.: Potential impact of iodine on tropospheric levels of ozone; other critical oxidants, J. Geophys. Res.-Atmos., 101, 2135-2147, 1996.

Dixneuf, S., Ruth, A. A., Vaughan, S., Varma, R. M., and Orphal, J.: The time dependence of molecular iodine emission from Laminaria digitata, Atmos. Chem. Phys., 9, 823-829, doi:10.5194/acp-9-823-2009, 2009.

Draxler, R. R. and Hess, G. D.: An overview of the HYSPLIT4 modeling system of trajectories, dispersion, and deposition, Aust. Meteor. Mag., 47, 295-308, 1998.

Furneaux, K. L., Whalley, L. K., Heard, D. E., Atkinson, H. M., Bloss, W. J., Flynn, M. J., Gallagher, M. W., Ingham, T., Kramer, L., Lee, J. D., Leigh, R., McFiggans, G. B., Mahajan, A. S., Monks, P. S., Oetjen, H., Plane, J. M. C., and Whitehead, J. D.: Measurements of iodine monoxide at a semi polluted coastal lo- 
cation, Atmos. Chem. Phys., 10, 3645-3663, doi:10.5194/acp10-3645-2010, 2010.

Gilles, M. K., Turnipseed, A. A., Talukdar, R. K., Rudich, Y., Villalta, P. W., Huey, L. G., Burkholder, J. B., and Ravishankara, A. R.: Reactions of $\mathrm{O}\left({ }^{3} \mathrm{P}\right)$ with alkyl iodides: rate coefficients and reaction products, J. Phys. Chem., 100, 1400514015, 1996.

Gómez Martín, J. C., Spietz, P., and Burrows, J. P.: Spectroscopic studies of the $\mathrm{I}_{2} / \mathrm{O}_{3}$ photochemistry - Part 1 : available at: Determination of the absolute absorption cross sections of iodine oxides of atmospheric relevance, J. Photochem. Photobio. AChem., 176, 15-38, 2005.

Gravestock, T. J., Blitz, M. A., and Heard, D. E.: A laser induced fluorescence study relating to physical properties of the iodine monoxide radical, Phys. Chem. Chem. Phys., 4, 823-834, 2010.

Heard, D. E., Read, K. A., Methven, J., Al-Haider, S., Bloss, W. J., Johnson, G. P., Pilling, M. J., Seakins, P. W., Smith, S. C., Sommariva, R., Stanton, J. C., Still, T. J., Ingham, T., Brooks, B., De Leeuw, G., Jackson, A. V., McQuaid, J. B., Morgan, R., Smith, M. H., Carpenter, L. J., Carslaw, N., Hamilton, J., Hopkins, J. R., Lee, J. D., Lewis, A. C., Purvis, R. M., Wevill, D. J., Brough, N., Green, T., Mills, G., Penkett, S. A., Plane, J. M. C., Saiz-Lopez, A., Worton, D., Monks, P. S., Fleming, Z., Rickard, A. R., Alfarra, M. R., Allan, J. D., Bower, K., Coe, H., Cubison, M., Flynn, M., McFiggans, G., Gallagher, M., Norton, E. G., O’Dowd, C. D., Shillito, J., Topping, D., Vaughan, G., Williams, P., Bitter, M., Ball, S. M., Jones, R. L., Povey, I. M., O’Doherty, S., Simmonds, P. G., Allen, A., Kinnersley, R. P., Beddows, D. C. S., Dall'Osto, M., Harrison, R. M., Donovan, R. J., Heal, M. R., Jennings, S. G., Noone, C., and Spain, G.: The North Atlantic Marine Boundary Layer Experiment(NAMBLEX). Overview of the campaign held at Mace Head, Ireland, in summer 2002, Atmos. Chem. Phys., 6, 2241-2272, doi:10.5194/acp-6-2241-2006, 2006.

Huang, R.-J., Seitz, K., Buxmann, J., Pöhler, D., Hornsby, K. E., Carpenter, L. J., Platt, U., and Hoffmann, T.: In situ measurements of molecular iodine in the marine boundary layer: the link to macroalgae and the implications for $\mathrm{O}_{3}, \mathrm{IO}, \mathrm{OIO}$ and $\mathrm{NO}_{\mathrm{x}}$, Atmos. Chem. Phys., 10, 4823-4833, doi:10.5194/acp-10-48232010, 2010.

Kraus, S.: DOASIS: a framework design for DOAS, Ph.D. thesis, Combined Faculties for Mathematics and for Computer Science, University of Mannheim, available at: http://hci.iwr. uni-heidelberg.de/publications/dip/2006/Kraus_PhD2006.pdf, 2005.

Küpper, F. C., Carpenter, L. J., McFiggans, G. B., Palmer, C. J., Waite, T. J., Boneberg, E.-M., Woitsch, S., Weiller, M., Abela, R., Grolimund, D., Potin, P., Butler, A., Luther, G. W., Kroneck, P. M. H., Meyer-Klaucke, W., and Feiters, M. C.: Iodide accumulation provides kelp with an inorganic antioxidant impacting atmospheric chemistry, P. Natl. Acad. Sci. USA, 105, 6954-6958, doi:10.1073/pnas.0709959105, http:// www.pnas.org/content/105/19/6954.abstract, 2008.

Mahajan, A. S., Oetjen, H., Saiz-Lopez, A., Lee, J. D., McFiggans, G. B., and Plane, J. M. C: Reactive iodine species in a semi-polluted environment, Geophys. Res. Lett., 36, L16803, doi:10.1029/2009GL038018, 2009.

Mahajan, A. S., Sorribas, M., Gómez Martn, J. C., MacDonald, S. M., Gil, M., Plane, J. M. C., and Saiz-Lopez, A.: Concur- rent observations of atomic iodine, molecular iodine and ultrafine particles in a coastal environment, Atmos. Chem. Phys., 11, 2545-2555, doi:10.5194/acp-11-2545-2011, 2011.

Mäkelä, J. M., Hoffmann, T., Holzke, C., Väkevä, M., Suni, T., Mattila, T., Aalto, P. P., Tapper, U., Kauppinen, E. I., and O'Dowd, C. D.: Biogenic iodine emissions and identification of end-products in coastal ultrafine particles during nucleation bursts, J. Geophys. Res., 107, 8110, doi:10.1029/2001JD000580, 2002.

Merten, A., Tschritter, J., and Platt, U.: Design of differential optical absorption spectroscopy long-path telescopes based on fiber optics, Appl. Opt., 50 (5), 738-754, 2011.

McFiggans, G., Coe, H., Burgess, R., Allan, J., Cubison, M., Alfarra, M. R., Saunders, R., Saiz-Lopez, A., Plane, J. M. C., Wevill, D., Carpenter, L., Rickard, A. R., and Monks, P. S.: Direct evidence for coastal iodine particles from Laminaria macroalgae linkage to emissions of molecular iodine, Atmos. Chem. Phys., 4, 701-713, doi:10.5194/acp-4-701-2004, 2004.

McFiggans, G., Bale, C. S. E., Ball, S. M., Beames, J. M., Bloss, W. J., Carpenter, L. J., Dorsey, J., Dunk, R., Flynn, M. J., Furneaux, K. L., Gallagher, M. W., Heard, D. E., Hollingsworth, A. M., Hornsby, K., Ingham, T., Jones, C. E., Jones, R. L., Kramer, L. J., Langridge, J. M., Leblanc, C., LeCrane, J.-P., Lee, J. D., Leigh, R. J., Longley, I., Mahajan, A. S., Monks, P. S., Oetjen, H., Orr-Ewing, A. J., Plane, J. M. C., Potin, P., Shillings, A. J. L., Thomas, F., von Glasow, R., Wada, R., Whalley, L. K., and Whitehead, J. D.: Iodine-mediated coastal particle formation: an overview of the Reactive Halogens in the Marine Boundary Layer (RHaMBLe) Roscoff coastal study, Atmos. Chem. Phys., 10, 2975-2999, doi:10.5194/acp-10-2975-2010, 2010.

O'Dowd, C. D. and Hoffmann, T.: Coastal new particle formation: a review of the current state-of-the-art, Environ. Chem., 2, 245, doi:10.1071/EN05077, 2005.

O’Dowd, C. D., Jimenez, J. L., Bahreini, R., Flagan, R. C., Seinfeld, J. H., Hameri, K., Pirjola, L., Kulmala, M., and Jennings, S. G.: Marine aerosol formation from biogenic emissions, Nature, 417, 632-636, 2002.

Peters, C., Pechtl, S., Stutz, J., Hebestreit, K., Hönninger, G., Heumann, K. G., Schwarz, A., Winterlik, J., and Platt, U.: Reactive and organic halogen species in three different European coastal environments, Atmos. Chem. Phys., 5, 3357-3375, doi:10.5194/acp-5-3357-2005, 2005.

Platt, U. and Stutz, J.: Differential Optical Absorption Spectroscopy, Principles and Applications, Physics of Earth and Space Environments Volume, Springer-Verlag Berlin Heidelberg, ISBN:978-3-540-21193-8, 2008.

Read, K. A., Mahajan, A. S., Carpenter, L. J., Evans, M. J., Faria, B. V. E., Heard, D. E., Hopkins, J. R., Lee, J.D., Moller, S. J., Lewis, A. C., Mendes, L. McQuaid, J. B., Oetjen, H., Saiz-Lopez, A., Pilling, M. J., and Plane, J. M. C.: Extensive halogen-mediated ozone destruction over the tropical Atlantic Ocean, Nature, 453, 1232-1235, doi:10.1038/nature07035, 2008.

Rosenfeld, D., Lohmann, U., Raga, G., O’Dowd, C., Kulmala, M., Fuzzi, S., Reissell, A., and Andreae, M.: Flood or drought: how do aerosols affect precipitation?, Science, 321, 1309-1313, 2008.

Rothman, L. S., Jacquemart, D., Barbe, A., Benner, D., Birk, M., Brown, L. R., Carleer, M. R. C. C. J., Chance, K., Coud- 
ert, L. H., Dana, V., Devi, V. M., Flaud, J.-M., Gamache, R. R., Goldman, R., Hartmann, J.-M., Jucks, K. W., Maki, A. G., Mandin, J.-Y., Massie, S. T., Orphal, J., Perrin, A., Rinsland, C. P., Smith, M. A. H., Tennyson, J., Tolchenov, R. N., Toth, R., Auwera, J. V., Varanasi, P., and Wagner, G.: The HITRAN 2004 molecular spectroscopic database, J. Quant. Spectrosc. Ra., 96, 139-204, 2005.

Saiz-Lopez, A. and Plane, J. M. C.,: Novel iodine chemistry in the marine boundary layer, Geophysical Research Letters, 31, L04112, doi:10.1029/2003GL019215, 2004.

Saiz-Lopez, A., Saunders, R. W., Joseph, D. M., Ashworth, S. H., and Plane, J. M. C.: Absolute absorption cross-section and photolysis rate of I2, Atmos. Chem. Phys., 4, 1443-1450, doi:10.5194/acp-4-1443-2004, 2004.

Saiz-Lopez, A., Shillito, J. A., Coe, H., and Plane, J. M. C.: Measurements and modelling of $\mathrm{I}_{2}, \mathrm{IO}, \mathrm{OIO}, \mathrm{BrO}$ and $\mathrm{NO}_{3}$ in the mid-latitude marine boundary layer, Atmos. Chem. Phys., 6, 1513-1528, doi:10.5194/acp-6-1513-2006, 2006a.

Saiz-Lopez, A., Plane, J. M. C., McFiggans, G., Williams, P. I., Ball, S. M., Bitter, M., Jones, R. L., Hongwei, C., and Hoffmann, T.: Modelling molecular iodine emissions in a coastal marine environment: the link to new particle formation, Atmos. Chem. Phys., 6, 883-895, doi:10.5194/acp-6-883-2006, 2006b.

Sander, S. P., Friedl, R. R., Golden, D. M., Kurylo, M. J., Moortgat, C. K., Keller-Rudek, H., Wine, P. H., Ravishankara, A. R., Kolb, C. E., Molina, M. J., Finlayson-Pitts, B. J., Orkin, V. L., and Huie, R. E.: Chemical kinetics and photochemical data for use in stratospheric studies, Evaluation number 15, NASA Jet Propulsion Laboratory, Publication 06-2, 2006.

Saunders, R. W., Kumar, R., Gómez Martín, J. C., Mahajan, A. S., Murray, B. J., and Plane, J. M. C.: Studies of the Formation and Growth of Aerosol from Molecular Iodine Precursor, Zeitschrift für Physikalische Chemie, 224(7-8), 1095-1117, doi:10.1524/zpch.2010.6143, 2010.

Seitz, K., Buxmann, J., Pöhler, D., Sommer, T., Tschritter, J., Neary, T., O'Dowd, C., and Platt, U.: The spatial distribution of the reactive iodine species IO from simultaneous active and passive DOAS observations, Atmos. Chem. Phys., 10, 2117-2128, doi:10.5194/acp-10-2117-2010, 2010.

Sellegri, K., Yoon, Y. J., Jennings, S. G., O’Dowd, C. D., Pirjola, L., Cautenet, S., Chen, H., and Hoffmann, T.: Quantification of Coastal New Ultra-Fine Particles Formation from In situ and Chamber Measurements during the BIOFLUX Campaign, Environ. Chem., 2(4), 260-270, doi:10.1071/EN05074, 2005.
Sommariva, R., Bloss, W. J., Brough, N., Carslaw, N., Flynn, M., Haggerstone, A.-L., Heard, D. E., Hopkins, J. R., Lee, J. D., Lewis, A. C., McFiggans, G., Monks, P. S., Penkett, S. A., Pilling, M. J., Plane, J. M. C., Read, K. A., Saiz-Lopez, A., Rickard, A. R., and Williams, P. I.: $\mathrm{OH}$ and $\mathrm{HO}_{2}$ chemistry during NAMBLEX: roles of oxygenates, halogen oxides and heterogeneous uptake, Atmos. Chem. Phys., 6, 1135-1153, doi:10.5194/acp-6-1135-2006, 2006.

Spietz, P., Gómez-Martín, J., and Burrows, J. P.: Spectroscopic studies of the $\mathrm{I}_{2} / \mathrm{O}_{3}$ photochemistry - Part 2. Improved spectra of iodine oxides and analysis of the IO absorption spectrum, J. Photochem. Photobio. A-Chem., 176, 50-67, 2005.

Stutz, J. and Platt, U.: Numerical analysis and estimation of the statistical error of differential optical absorption spectroscopy measurements with least-squares methods, Appl. Opt., 35, 60416053, 1996.

Stutz, J., Pikelnaya, O., Hurlock, S. C., Trick, S., Pechtl, S. and von Glasow, R.: Daytime OIO in the Gulf of Maine, Geophys. Res. Lett., 34, L22816, , doi:10.1029/2007GL031332, 2007.

Voigt, S., Orphal, J., and Burrows, J. P.: The temperature and pressure dependence of the absorption cross-sections of $\mathrm{NO}_{2}$ in the $250-800 \mathrm{~nm}$ region measured by Fourier-transform spectroscopy, J. Photoch. Photobio. A, 149, 1-7, 2002.

Wada, R., Beames, J. M., and Orr-Ewing, A. J.: Measurement of IO radical concentrations in the marine boundary layer using a cavity ring-down spectrometer, J. Atmos. Chem., 58, 69-87, 2007.

Whitehead, J. D., McFiggans, G. B., Gallagher, M. W., and Flynn, M. J.: Direct linkage between tidally driven coastal ozone deposition fluxes, particle emission fluxes, and subsequent CCN formation, J. Geophys. Res., 36, L04806, doi:10.1029/2008GL035969, 2009.

Whalley, L. K., Furneaux, K. L., Gravestock, T., Atkinson, H. M., Bale, C. S. E., Ingham, T., Bloss, W. J., and Heard, D. E.: Detection of iodine monoxide radicals in the marine boundary layer using laser induced fluorescence spectroscopy, J. Atmos. Chem., 58, 19-39, 2007.

Yokelson, R. J., Burkholder, J. B., Fox, R. W., Talukdar, R. K., and Ravishankara, A. R.: Temperature dependence of the $\mathrm{NO}_{3}$ absorption spectrum, J. Phys. Chem., 98, 13144-13150, 1994. 